\title{
Possibilities For Managing Financial Crises Of Macedonian Companies $^{*}$
}

\author{
Biljana ANGELOVA** \\ Neda PETROSKA-ANGELOVSKA*** \\ Marija ACKOVSKA ${ }^{* * * *}$
}

\section{ABSTRACT}

Frequent economic crisis, led a large number of companies to cumulate losses. On these conditions are not immune Macedonian companies, also. Such businesses, if not undertake adequate measures, over time, become indebted and lose solvency, or are facing a serious problem - financial crises. Considering that the recovery from financial crisis is very difficult process, it is especially important companies to undertake certain actions that would prevent the occurrence and escalation of the crisis.

In that context, main objectives of this paper is to identify the main causes of financial crisis of companies, briefly to present current methods of managing financial crisis as strategies whose implementation will prevent the liquidation of companies and to explore the level of implementation of financial restructuring, merger and acquisition and turnaround concept in companies of Republic of Macedonia. For that purpose, different qualitative and quantitative methods are implemented. For collecting primary data from companies in the Republic of Macedonia, constructed questionnaire is used. The analysis will lead to achievement of main goal of the paper and will contribute to identify the frequently used opportunities for managing and overcoming financial crisis of companies in the Republic of Macedonia.

Findings will direct to the following: there is no unified way for managing financial crisis, that could be applied in any company and that common in application of current ways to overcome the financial crisis (turnaround concept, financial restructuring, merger and acquisition of companies) is that their adequate implementation contributes to improving efficiency and effectiveness in managing the financial crisis and subsequently have positive implications company performances.

Keywords: Financial crises, companies, financial restructuring, merger and acquisition, turnaround concept.

\footnotetext{
* This article was presented as a paper at the IV. International Symposium on Accounting and Finance in Ohrid, Macedonia, July 3-5, 2017.

${ }^{* *}$ Prof. Biljana Angelova, Institute of economics-Skopje, University “St. Cyril and Methodius",ul. Prolet br.1,angelova@ek-inst.ukim.edu.mk.

*** Prof. Neda Petroska-Angelovska, Institute of economics-Skopje, University "St. Cyril and Methodius",ul. Prolet br.1, neda@ek-inst.ukim.edu.mk

${ }^{* * * *}$ Assoc. Prof. Marija Ackovska' Institute of economics-Skopje, University "St. Cyril and Methodius", ul. Prolet br.1, marija@ek-inst.ukim.edu.mk
} 


\section{INTRODUCTION}

The dynamic environment implies the need for greater emphasis of companies on possibilities of a financial crisis outbreak in their performance. Lack of solution or inadequate solution to this problem can direct company to process of liquidation. The recovery process of companies in financial crisis is very complex one and needs a very deep analyses of the main causes for that situation. From that point of view, this paper particularly emphasized the importance of the establishment and operation of crisis management in companies that are facing crisis.

If it is pointed the fact that in Republic of Macedonia the number of liquidated companies is much larger than the number of companies that successfully manage to overcome the financial crisis and continue to work, then the presentation of the measures and strategies of crisis management are in order to improve the effectiveness of dealing with the crisis. So, it is stressed the importance of three main ways for crisis management and overcoming it, as following: financial restructuring, merger and acquisition of companies and turnaround concept.

\section{METHODOLOGY}

For the purpose of this paper different qualitative and quantitative methods are implemented. In the process of collecting and processing data, and in the process of drawing conclusions and recommendations in preparation of research mainly are used the following methods: inductive method, deductive method, method of comparative analysis, historical method, method of trend analysis etc.

The use of inductive and deductive method is in order to ensure that conclusions result from long line analytical basis. Applying of method of comparative analysis enables identifying the differences in social and economic factors and conditions in different countries that causes such crisis. Historical method is used in consideration of ways for managing financial crisis in our country. Also there are applied certain qualitative and quantitative techniques to collect data for research, such as case studies, scientific observation, collecting and processing of inquiry data.

During the preparation of paper were used multiple sources of data, information and theoretical knowledge, such as: relevant domestic and foreign literature for definition of financial crisis in companies and an indication of the main reason for such crisis, domestic and foreign literature on the organizing and activities of crisis management in companies, domestic and foreign literature on the types and application of statistical models to predict the financial crisis in companies, domestic and foreign literature in electronic form from relevant internet links to current strategies to overcome the financial crisis (with particular emphasis on financial restructuring, mergers and acquisitions, turnaround concept), laws and regulations, analysis of statistical data from the financial statements of companies etc.

To see if applicable, to what extent and which models are applied to predict the financial crisis of macedonian companies, 41 companies were surveyed during the year 2016. Enterprises belong to different industries including: heavy industry, food industry, textile iindustry, shoe industry, construction industry, manufacturing, retail, wholesale, 
printing industry, insurance industry, transport, accounting, financial industry, tourism and hospitality industry. Structure of surveyed companies, according to the number of emploees were as follows: thirteen (32\%) are in the category of up to 9 employees, seventeen $(41 \%)$ in the category up to 49 employees, eight (20\%) in the category up to 250 employees, one (2\%) in the category over 250 employees in the enterprise and two companies not answer this question from the questionnaire.

\section{MODELS FOR PREDICTING FINANCIAL CRISES OF COMPANIES}

Amid frequent economic crises, when a large number of enterprises are facing insolvency, it is important, based on models for predicting the financial crisis, promptly to recognized the possibilities of the occurrence of the crisis. The benefit of predicting the financial crisis is reflected in the creation of a series of advantages which the company will use in dealing with, which is much more efficient and effective way.

\section{Table 1. Impact Of Prediction Of The Crisis On Minimizing The Negative Effects Of The Crisis}

\begin{tabular}{|l|r|r|}
\hline $\begin{array}{c}\text { Crisis prediction } \\
\text { minimizes the } \\
\text { negative effects }\end{array}$ & $\begin{array}{c}\text { Number of } \\
\text { answers }\end{array}$ & $\%$ \\
\hline Yes & 24 & $59 \%$ \\
\hline No & 1 & $2 \%$ \\
\hline Sometimes & 11 & $27 \%$ \\
\hline Not answered & 5 & $12 \%$ \\
\hline Total & 41 & $100 \%$ \\
\hline \multicolumn{2}{|l|}{ Source: Processed data from a survey conducted }
\end{tabular}

Crisis in enterprises is characterized by reducing the resources of the company that occures as a result of the reduction of its ability to adapt to specific segments of the environment in which it works. In fact, in a crisis the company is in a stage which threatened the goals of vital importance of company i.e. existential goals as follows (Gurma, 2010: 25):

- $\quad$ Liquidity and financial balance,

- $\quad$ Achieving a minimum profit or cover costs,

- $\quad$ The preservation and restoration of the basic prerequisites for success.

Means that, financial crisis in company occurs when it is losing or has lost solvency, i.e. becoming over-indebted. The decline in business success and working with loss, further deteriorating and limited chance of funding from creditors. If company try to hide the true size of the crisis, it will further deepen and liquidity will increase. Timely taken measures to prevent the emergence and escalation of crisis is the most important requirement for long and continuous operation of the company. Therefore, predicting the financial crisis in modern economic conditions is of increasing importance and application of models for predicting the financial crisis in companies 
contributes to minimizing the negative effects of the financial crisis in the operation of the enterprise. Typically, models to predict the crisis in which the company based on accounting data are grouped (Hand and Henley, 1997: 523-541):

- $\quad$ Univariable models and

- $\quad$ Multivariable models.

Univariable models based on comparing the different financial indicators of the company with industry standards, i.e. branch standards which company belongs to. Such a statistical model to predict financial failure is the model of Beaver (Beaver, 1993: 231-235). Beaver was first performed testing the usability of financial indicators in predicting financial failure. The financial failure as viewed the "inability of the company to pay maturing obligations." (Beaver, 1988:154-165) This failure leads to business difficulties that the author of this model defines how ,, bankruptcy, unpaid preferred dividends, raising loans on current accounts and so on. "And financial indicators that could predict business difficulties and financial failure as, ratio of two numbers that are items in the financial statements(Beaver, 1988:178)."

When using multivariable models, key accounting variables are combined so, in order to obtain the probability of delays in the enterprise repayment. In current practice is mostly applied discrimination analysis, and the first model that applied this approach was Altman's z-score model. This model, combins the values of tcompany, get a measure (i.e. credit risk score) that best distinguish between successful and unsuccessful businesses. In order to create a model that will perform classifying companies on one that will go to bankrupt and those who will not go bankrupt, Haldeman and Narayanan created the ZETA model (Altman, 1977: 431). Later Scott performed a comparison between numerous empirical and theoretical models and comes to the conclusion that the ZETA model most closely approximates the theoretical model of bankruptcy (Altman, 1977: 431).

The model Springat (Efrim, 2007:67) is applied in Canada and is an example of adjusting Altman's model in different economic conditions with the difference that this model uses four variables calculated based on accounting data.

Klaricek's Quicktest is applied in the countries of Central Europe and was created to be used to assess the financial performance of the companies. It differs from Altman's model in static and dynamic performance (Koban, 1978:3.)

Characteristic of all models is predicting that financial crisis has made based on the variables - calculated accounting data. Although it is a credit risk models used in banking, their application is desirable in the companies themselves precisely because the accuracy of the predictions of the financial crisis is relatively high.

The specifics of the operation of the company in crisis requiring the existence of crisis management. The purpose of the establishment of crisis management should be, above all, prevention of crisis, and if this occurs, taking measures to overcome it. The responsibility of crisis management becomes greater with increasing escalation of the crisis, because how the crisis is intense, the company is closer to bankruptcy 
proceedings and its liquidation. Therefore, crisis management should be established and continuously acts as a separate segment in the organizational structure of company, not its creation and existence to be associated only with the period of the emergence and existence of crisis. The existence of a professional and well-informed crisis management which monitors changes in and outside the company, and is well versed in the threats and opportunities of the performance of the company.

Table 2. The existence of an active crisis management in companies in Macedonia

\begin{tabular}{|l|r|r|}
\hline \multicolumn{1}{|c|}{$\begin{array}{c}\text { Existence of an active crisis } \\
\text { management }\end{array}$} & $\begin{array}{c}\text { Number } \\
\text { of answers }\end{array}$ & \% \\
\hline $\begin{array}{l}\text { Exists and undertakes } \\
\text { complete activities }\end{array}$ & 6 & $15 \%$ \\
\hline $\begin{array}{l}\text { Exists and undertakes partial } \\
\text { activities }\end{array}$ & 6 & $15 \%$ \\
\hline No active crisis management & 25 & $61 \%$ \\
\hline Not answered & 4 & $10 \%$ \\
\hline Total & 41 & $100 \%$ \\
\hline
\end{tabular}

Source: Processed data from a survey conducted

Table 3. Application of models for predicting the financial crisis in Macedonia

\begin{tabular}{|l|r|r|r|r|r|r|}
\hline \multicolumn{1}{|c|}{ Models for predicting } & \multicolumn{1}{c|}{$\begin{array}{c}\text { Very } \\
\text { often }\end{array}$} & \multicolumn{1}{c|}{ Often } & \multicolumn{1}{c|}{ Rare } & Never & \multicolumn{1}{c|}{$\begin{array}{c}\text { Not } \\
\text { answered }\end{array}$} & Total \\
\hline Beaver model & 1 & 1 & 8 & 14 & 17 & 41 \\
\hline Altmanov Z-score model & 0 & 1 & 3 & 15 & 22 & 41 \\
\hline Zeta model & 0 & 0 & 4 & 15 & 22 & 41 \\
\hline Klaricekov Quick test & 0 & 2 & 3 & 14 & 22 & 41 \\
\hline Other models & 2 & 6 & 12 & 8 & 13 & 41 \\
\hline Total & 3 & 10 & 30 & 66 & 96 & 205 \\
\hline
\end{tabular}

Source: Processed data from a survey conducted

Table 4. Willingness Of Enterprises In The Country To Deal With Financial Crisis

\begin{tabular}{ccc} 
Level of preparation & Number of responses & Percent \\
\hline Complete ready & 7 & $17 \%$ \\
\hline Partially prepared & 23 & $56 \%$ \\
\hline Not ready & 8 & $20 \%$ \\
\hline No answer & 3 & $7 \%$ \\
\hline Total & 41 & $100 \%$ \\
\hline
\end{tabular}

Source: Processed of data from a survey conducted

Lack of objectivity in assessment of their own situation, the lack of experience to quick and effective react in crisis situations, and lack of strategies and courage, are main obstacles to management in dealing with the crisis. Financial analysis as a basis for financial decision making has great importance in the turbulent economic conditions of 
action and crisis, because the perception of the real financial situation of the company is the basis for proper business decision that is directed toward resolving insolvency and recovery of the financial situation, thus remove hazards from the liquidation of the company. Information obtained from the funding analysis form is the basis for selection of proper strategy for tackling the financial crisis and basis for adequate managing of crisis situation of company.

\section{POSSIBLE STRATEGIES FOR MANAGING FINANCIAL CRISIS IN MACEDONIAN COMPANIES}

The recovery of the company largely depends on the choice of appropriate strategies that could solve fundamental problems and eliminate the causes for the occurrence of the crisis (meaning strategies that will not focus on the symptoms of the crisis, but the reasons). Also, choosing a strategy that treats not only one reason causing the crisis in the company, no matter how the cause is serious, it will be unsuccessful, and limited resources will be spent on areas that will lead to the crisis. In focus of strategy should be all problems that threaten the survival of the company.

Recovery strategies are not only actions, but should be adjusted according to the phase of recovery and the effectiveness of previous activities in company. The success of previous actions affects the selection of strategies for recovery and the success of process of recovery. Also, intensive implementation of strategies is not a sufficient condition for the crisis. As a necessary condition imposes the identification of factors that influence the choice of an adequate strategy.

The large number of factors that determine the choice of strategies for recovery of company crisis, as most relevant are the following:

- The causes of crisis;

- Crisis difficulty;

- Stage of development of crisis;

- The available resources of company;

- Specific characteristics of company (size, diversification, previously undertaken activities, history of company etc.);

- The life cycle of company;

- Industry characteristics that accounts for the company;

- The competitive position of company;

- Attitudes of key stockholders.

Current approaches to overcome the crisis in enterprises receive special significance in recent decades when the number of subjects who fall into crisis is much greater. The financial restructuring is one of the strategies that the crisis provides an opportunity for commercial entities to "rehabilitate" and adapt to the dynamic changes in the environment. Basically, financial restructuring is a reactivation of their own potential company. Through changes in the capital structure and changes in financial policy and financial restructuring should be aimed at adapting the company to the new conditions of work and solving the problems of insolvency and over-indebtedness. Therefore, at some stage of the escalation of the crisis, financial restructuring is an opportunity to save the companies from liquidation. 
One of the reasons why the crisis management in most cases the preferred financial restructuring is that this strategy is probably the fastest, most painless and most useful way to overcome the financial crisis, because based on a serious analysis of the current situation, the assessment of the weaknesses and strengths of the company, it is made a selection of adequate targets to be achieved by restructuring. Realization the general objectives of financial restructuring effected by: changing the terms of financing and reduction of debt of the company, providing liquidity and address the problem of illiquidity, the cleaning of balance and tackling the cumulated loss and by creating a favorable structure capital to more efficient operation of the enterprise.

Mergers and acquisitions of companies is a strategy that is actualized in the last two - three decades and is applied mostly as a strategy of growth and development of enterprises. As a result of the merger and acquisition, companies realize multiple benefits in terms of reducing operating costs, gaining new markets, transfer of experiences, creating opportunities for the application of technical - technological development, increased utilization of production capacity more. If the company that applies these strategies in crisis, the synergistic effects of the application of this strategy also represent an opportunity to overcome the crisis because it is these effects will enable the company increased revenue, increased cash flows and adding value of the company. Synergistic effects of the merger and acquisition ultimately improve the financial performance of the company among other creates the possibility of using additional sources of capital. If you take into account that in times of economic crisis the banks have reduced their lending activities and become rigorous in terms of lending to companies with high financial debt, the merger and acquisition represent a real opportunity to overcome the financial crisis and maintain the continuity of operations of enterprise.The crisis in the company first appears as a latent crisis and if time does not take steps to address it, it can escalate to the point where only the sudden and rapid changes in utility operations (turnaround) you can overcome crisis and avoid company liquidation. Taking comprehensive changes in all segments of activity of the enterprise should lead to a turnaround in the business held by the operating loss will go to work with a positive financial result. In realizing the twist - the concept actually performed strategic and organizational restructuring of the company, which should remove the strategic and organizational mistakes in the operation of the enterprise, and thus eliminate the reasons that led to the occurrence of the crisis in the company. The final effect of comprehensive measures turned the operation of the company's reduction of debt, solving liquidity problems and achieving positive financial results.

Table 5. Implementation Of Strategies For Overcoming Financial Crisis

\begin{tabular}{|l|r|r|r|r|}
\hline $\begin{array}{l}\text { Implemented } \\
\text { strategy }\end{array}$ & \multicolumn{1}{|c|}{$\begin{array}{c}\text { Not } \\
\text { implemented }\end{array}$} & Implemented & \multicolumn{1}{c|}{$\begin{array}{c}\text { Not } \\
\text { answered }\end{array}$} & \multicolumn{1}{c|}{ Total } \\
\hline $\begin{array}{l}\text { Financial } \\
\text { restructuring }\end{array}$ & 13 & 16 & 12 & 41 \\
\hline M\&A & 19 & 5 & 17 & 41 \\
\hline Turnaround & 22 & 3 & 16 & 41 \\
\hline $\begin{array}{l}\text { Other } \\
\text { startegies }\end{array}$ & 18 & 10 & 13 & 41 \\
\hline
\end{tabular}

Source: Processed of data from a survey conducted 
Table 6. Macedonian Company's Prefered Startegies

\begin{tabular}{|l|r|r|}
\hline $\begin{array}{c}\text { Preferred strategy in case } \\
\text { of insolvency }\end{array}$ & $\begin{array}{c}\text { Number of } \\
\text { answers }\end{array}$ & \multicolumn{1}{c|}{$\%$} \\
\hline Financial restructuring & 21 & $51 \%$ \\
\hline M\&A & 6 & $15 \%$ \\
\hline Turnaround & 2 & $5 \%$ \\
\hline Other & 12 & $29 \%$ \\
\hline Total & 41 & $100 \%$ \\
\hline
\end{tabular}

Source: Processed of data from a survey conducted

The statement of the majority of respondents that applied no strategy suggests insufficient implementation of current strategies you Macedonia. The processed data of the survey highlight the strategy ,financial restructuring" as much more preferred strategy to address the problem of illiquidity and overcoming the crisis by businesses in the country.

\section{FINDINGS}

From the conducted research main findings arise. First of all, the analyze of collected data from conducted questionnaire direct to the point that there is no unified way for managing financial crisis, that could be applied in any company and that common in application of current ways to overcome the financial crisis (turnaround concept, financial restructuring, merger and acquisition of companies) is that their adequate implementation contributes to improving efficiency and effectiveness in managing the financial crisis and subsequently have positive implications company performances.

Next one is that success in managing and overcoming of financial crisis in company is testing the abilities and capabilities of the company's management. The lack of objectivity in the assessment of their own situation, the lack of experience to quickly and effectively react in crisis situations, and lack of strategies and courage are the main obstacles to the management in dealing with the crisis.

Current approaches to overcome the crisis (financial restructuring, mergers and acquisitions, turnaround concept) in companies have special importance in recent decades when the number of subjects that fall into crisis is much greater.

Better information of management reduces making inappropriate business decisions and increases efficiency in managing crisis of company. Based on the analysis to be carried out prior to the selection of strategies to overcome the crisis and, above all, based on the financial analysis that provides high level of required information, crisis management shall determine the measures to overcome the crisis. It indicates that using of financial indicators analysis in process of managing financial crisis in companies improves its efficiency.

According to collected data from the conducted research, in the opinion of companies in the Republic of Macedonia some of the measures that should be applied by domestic companies in order to successfully deal with the financial crisis are defined as: measures for provision of additional liquidity, measures to reduce indebtedness, 
measures to reduce costs and increase income, measures to accelerate the inflow of funds from current operations and measures to penetrate new markets and increase market share.

\section{CONCLUSIONS}

The crisis in companies first appears as a latent crisis and if measures for resolving are not taken on time, it can escalate to the point where only a sudden and rapid changes in utility operations, turnaround, can overcome the crisis and avoid unfavorable situation. Taking comprehensive changes in all segments of the companies' operations should lead to a turnaround in company performances.

To successfully overcome the crisis situation, crisis management should undertake a mix of activities to address the insolvency and over-indebtedness. It should be preferred activities that will lead to a definitive settlement of debt, as opposed to activities that only in short period of time will delay repayment of maturing obligations. Definitive resolution of debt and repayment of maturing obligations include provision of additional capital, but not as new borrowing (as is often the case in the Republic of Macedonia), but using its own liquidity reserves that will not further increase the debt of the company.

That's the reason why it is necessary in the periods in which the company operates with profit, to take appropriate measures and to protect themselves from escalating crisis periods when realized loss. Provisions for costs and risks for future periods and separation of financial reserve sources would allow the company to cover possible losses in future periods or minimize the consequences of possible financial crisis.

The research of the question of dealing with financial crisis in companies of theoretical and practical perspective, in this paper, attempts to create a base that would help companies to overcome this problem. The recommendations that are differentiated in the paper are the result of conclusions derived from conducted research in companies of the Republic of Macedonia.

\section{REFERENCES}

Block S., Hirt G, (2008), Osnove finansiskog menadzmenta, McGraw-Hill Irvin.

Velimirovic M.,(2003), Sadržaj i dejstvo stečajnog plana, Pravni život N. 11.

Janikijevic N. (2003), Organizacione promene u razvoj, Beograd.

Kokotec - Novak Majda, (1997)Racunovodski vidik sanacije podvjeta, Zbornik referatov 29 simpozija, osodobnih, metodah $\mathrm{v}$ racunovodstvu in poslovnih financah, Portoroz: Zveza ekonomistov Slovenije in zveza racunovodi, financnikov in revizorjev Slovenije.

Mićović M., (2004), Reorganizacija ili redresman stečajnog dužnika, Pravo i privreda, Volume: 5-8, Beograd. 
Miroslav M. Todorovik, (2005), Finansijsko restrukturiranje korporacija, Ekonomski fakultet, Beograd,

O’Neill, H. M., (1986), Turnaround and recovery: What strategy do you need?, Long Rang Creditor Rights in Insolvency Procedure", Sydney, November 1999, www.oecd.org

Pajunen K., (2005), Stakeholder Influences in Organizational Survival, Journal of Managment Studies.

Pittaluga Rodolfo Jr., (2000), U.S. Bankruptcy/Insolvency laws and foreign bankruptcy proceedings.

Richard A.,Stjuard C., Frenklin A., (2011), Principi na korporativnite finansii, Ars Lamina, Skopje.

Stieve M, Karoline G., (2012), Pretpriemastvo i upravuvanje so mali biznisi, Ars Lamina, Skopje.

Smith, M. i C. Graves, (2005), Corporate turnaround and financial distress, vol. 20 (3), Managerial Auditing Journal.

Stuart C. Gilson, (2006), Creating value through corporate restructuring, John Wiley \& Sons, Boston.

UNCITRAL, (2004), Legislative Guide on Insolvency Law (June), www.uncitral.org.

Freshfields Bruckhaus Deringer, (2004), The EU regulation on insolvency proceedings (June),www.freshfields.com.

European Bank for Reconstruction and Development, (2006), Transition Report.

http://www.coba.usf.edu/departments/management/

http://www.byrneassociates.co.uk/adrec.html

http://www.crm.com.mk

www.pravoeu.jura.kg.ac.yu

www.oecd.org

www.economics.ag.utc

www.wordlbank.org

Www.uncitral.org

www.economy.gov.mk 